\title{
Ecotourism Strategy for Indigenous Community to Contribute Socioeconomic Resilient in Pulau Merah Area
}

\author{
Magistyo P. Priambodo ${ }^{1 *}$, Ni'matul Istiqomah ${ }^{2}$, Nur A. Yunikawati ${ }^{3}$, Emma Y. $^{\prime}$ \\ Puspasari $^{4}$, Fatimah Sidi ${ }^{5}$
}

1,2,4,3 Universitas Negeri Malang, Malang, Indonesia

${ }^{5}$ Universiti Putra Malaysia, Selangor, Malaysia

*Corresponding author. Email: magistyo.purboyo.fe@um.ac.id

\begin{abstract}
Tourism has become one of the largest economic sectors and is the service sector with the fastest growth rate in the world today. Increasing the number of destinations and investing in tourism development, has transformed tourism as a prime mover the socio-economic progress of a country one of them is ecotourism. Ecotourism is a mixture of interests arising from environmental, economic, and social problems. It combines a strong commitment to nature and a sense of social responsibility. Pulau Merah is an ecotourism attraction in Banyuwangi which has huge potential and it developing very fast, up to the international level. This condition makes the surrounding community quite affected, especially the socio-economic aspects, as a result of which there are many tourist visits every year. This study aims to determine the contribution size of the socio-economic impacts that arise as a result of the rapid development of ecotourism. Other objectives will also be formulated to increase socio-economic resilience based on the strengths, weaknesses, opportunities and threats that exist there. The method used to answer the problems is a descriptive phenomenology approach, where the researcher makes direct observations, interviews and surveys supported with a simple SWOT analysis to be able revealing the real conditions that appear. The ecotourism give structural economic activity enhancement for local people; from agriculture activity become extensively service provider for tourism. There is evidence for increasing socio-economic welfare from developing ecotourism. Strategies must be carried out to create significant impact on socio-economic activities. Based on the results of the analysis carried out, there are several strategies concern in aspects of advantage, consistency, consonance and feasibility. The implementation are by increasing the participation of local residents in all age and improving eco-friendly infrastructure as well as supporting regulations as legal protection for tourism activities and education for conserving nature.
\end{abstract}

Keywords: Ecotourism, Tourism strategy, Tourism community

\section{INTRODUCTION}

The tourism sector is widely recognized as a sector that can develop other sectors to increase economic growth. Even the tourism sector is expected to be the largest source of foreign exchange in a region so that the tourism sector needs to be developed. Tourism has become one of the largest economic sectors and is the service sector with the fastest growth rate in the world today. Increasing the number of destinations and investing in tourism development, has transformed tourism as a prime mover the socio-economic progress of a country through acceptance foreign exchange, creating jobs and opportunities undertaking, as well as infrastructure development. The world tourism organization (World Tourism Organization) UNWTO predicts international tourists will reach 1.8 billion in 2030 with a growth rate of visits for the Asia and Pacific region reaching 4.9 percent per year [1]. As the main component in tourism, the community, especially the local community has a very important role in development and tourism development. Local people indirectly feel the impact of tourism, both social and economic impacts [2]. Many countries in the world are racing and improving themselves to build their tourism industries. The world competition is very tight, coupled 
with the threat of global economic and political crises that are still being experienced by many countries. In recent years, as well as the current Covid-19 pandemic, it requires innovation and appropriate and productive strategies to seize the market tourism. This is an opportunity as well as a challenge for the development of tourism in Indonesia in supporting socio-economic resilience for community.

For Indonesia, the role of tourism is increasingly felt, especially after the weakening role of oil and gas, although the nominal value in dollars has fluctuated. Visits of foreign tourists show an upward trend in several decades, in 1969 Indonesia was visited by only 86.067 foreign tourists, and then increased to 2.051.686 in 1990 and 5.064.217 in 2005. The arrival of these foreign tourists has provided huge foreign exchange earnings to Indonesia. Foreign exchange received consecutively in 1996, 1997, 1998, 1999 and 2005 was 6,307.69; 5,321.46; 4,331.09; 4, 710.22 and 5,748.80 million US Dollars [3]. The role of tourism in economic activity is obviously positive from the statistics presented previously. But tourism is not only an economic problem, but also a social, cultural, political and environmental problem. Tourism activity is a multicomplex system, with various aspects that are interrelated and influence each other. In the last few decades, tourism has become a source for driving the dynamics of society and being one of the prime movers in socio-cultural change.

The existence of a tourist attraction is very dependent on the local government, tourists and local communities. Local government as the manager of tourism objects must be able to see tourists as a determining factor and become a top priority. Apart from tourists, local communities play an important function for sustainability business objects and tourist attractions [4]. This means that the position of the local community is a driving factor as well as supervision for the course of the tourism industry business in the area [5]. Thus, a synergistic relationship will be created in the development of tourism objects, because local governments, local communities and tourists have a big share in advancing tourist destination [6]. Marketing strategy placement that is always faced is how a social and managerial process, by which individuals and groups get what they need and want, by creating and exchanging products [7]. Selection in making a good strategy and precisely can be fulfilled by using several benchmark strategies for tourism expose. According to Rumelt [8] there are several benchmarks including the following; 1) advantage, 2) consistency, 3) consonance, and 4) feasibility.

Ecotourism is traveling activity to some pristine natural location with specific objective to study, admiring, enjoying the scenery and flora fauna as well as any cultural manifestation found in that area [9].
Ecotourism is a mixture of interests arising from environmental, economic, and social problems. It combines a strong commitment to nature and a sense of social responsibility. It's about creating and satisfying hunger for nature, about exploiting the potential of tourism for conservation and development [10][11]. In developing an area for ecotourism activities, it is necessary to carry out an inventory to determine the potential advantages of the attractions that become its attractions [12]. In general, natural tourist attractions found in an eco-tourism development area are the use of rivers, reservoirs, forests, beaches, waterfalls, and caves [13]. utilization of natural resources and the environment as well as concern for surrounding communities in nature conservation areas in line with the vision of ecotourism development, which is protection of biodiversity and its ecosystem and empowerment of indigenous peoples [14][15][16]. This vision is a reference in implementing ecotourism activities which all aim at conserving nature and improving the welfare of the community [17][18]. According to Chesworth[19], Ecotourism has six elements. These are: a) ecotourism involves traveling to natural areas and / or uninterrupted archaeological sites, b) based on learning and quality experiences, c) economically beneficial to local communities, d) ecotourism seeks to see rare species, spectacular surveillance and / or the unusual and exotic, e) ecotourism does not drain resources but even conserves the environment or helps repair environmental damage, and f) ecotourism respects and respects local culture, traditions, etc.

Banyuwangi is a district which is located at the eastern tip of Java Island where there are many tourist objects ranging from natural tourism, artificial tourism, religious tourism, city tourism and cultural customs. Sumberagung Village is the only village in Banyuwangi Regency has a variety of tourism potentials with a leading tour, namely Pulau Merah tourism site. This island is known for its small green hills with red soil located near the shoreline. This hill can be explored on foot at low tide time. Since the introduction of Pulau Merah through the International Surfing competition, many tourists have come to enjoy the beauty of the tour. Many tourists or visitors who come will have an impact on the socio-economic conditions of the surrounding community [20][21]. During several periods the increase in the number of tourist visits to the Pulau Merah tourist attraction continued to increase with the development of tourist activities which exists. According to the Pulau Merah community group Secretary the number of tourist visits is increasing, in 2018 the number of tourist visits was around 210 thousand visitors and in 2019 more than 330 thousand visitors.

Consideration of the background condition of tourism in Indonesia, especially Banyuwangi district as 
well as the context of the strategy for developing Pulau Merah beach tourism as above. Researchers want to do further research about the existing impact from ecotourism for socio-economics indigenous community. Furthermore, this study aims to observe, evaluate, and provide a strategic model through expert opinion in terms of tourism development, especially the management and empowerment of the Red Island Beach tourism community which is related to Indonesia's wonderful strategy, especially sunrise van Java. specifications needed for preparing electronic versions of their papers. All standard paper components have been specified for three reasons: (1) ease of use when formatting individual papers, (2) automatic compliance to electronic requirements that facilitate the concurrent or later production of electronic products, and (3) conformity of style throughout a conference proceeding.

\section{METHODS}

This type of research is descriptive research. The method used is a phenomenological approach. This research was conducted in January - August 2020 in Sumberagung Village, Pesanggaran Subdistrict, Banyuwangi Regency. The method used in determining informants using snowball sampling technique. The type of data used in this study consists of primary data and secondary data. Methods of data collection are carried out by documentation, interviews and observations. To test the data, the triangulation technique was used, namely by comparing the data obtained in the interview with the observation data. Technique data analysis by doing: (a) data collection on place of research, (b) data reduction, namely selecting, make a summary or brief description, (c) present the data by manifesting in the form of a matrix, graphic, network or chart, (d) drawing conclusions. SWOT analysis use to determine the possible strategy for developing ecotourism based on potential condition.

\section{RESULTS AND DISCUSSION}

Pulau Merah beach area is located in sumberagung which has a famous landscape in the form of an island located $50 \mathrm{~m}$ from the beach and $200 \mathrm{~m}$ high with reddish soil. Coastal charm also comes from the cluster of small islands around it that save beauty for tourist purposes. The characteristics of the Pulau Merah beach can be shown from the physical condition, characteristics and characteristics of all tourist objects which include the state of the land, water, climate, and the existing ecosystem. Natural resources that are owned there are a priority driving the development of marine tourism activities, while the core of natural resources that form the characteristics of the coast of Pulau Merah. The natural beauty of the beach and the natural environmental conditions around the area are still great potential as tourist attractions [22].
The existing population is 13,968 people with a percentage of $49 \%$ male and $51 \%$ female. There are many rice fields, horticultural fields and water area suitable for agricultural activities. The majority of the populations are farmers, if it is seen from the amount of agricultural land available. The level of education in the Sumberagung area is quite good because $48 \%$ have received formal education. Pulau Merah beach tourism is one of the tours listed in Tourism Developing Area (Wilayah Pengembangan Pariwisata) III in Banyuwangi district. So far, the management of Pulau Merah beach tourism objects in Banyuwangi district has been managed by the surrounding community by forming the Pulau Merah beach Working Group (Pokmas) under Forest Area Community Institutions (LMDH). The management carried out by the Pokmas collaborates with the Perhutani Office, so that the development of the tourism potential of the Pulau Merah coast optimizes activities that are oriented towards the strength of private community capital and local community selfprovide.

The arrival of visitors or tourists will have its own impact on economic activity in a tourist area. Based on data obtained at the Pulau Merah Pokmas, in March 2018 the number of tourist visits was 18,199 visitors. If in one month the number of visitors reaches almost 20 thousand visitors, it can be predicted that in one year the number of visitors to Pulau Merah can reach 250 thousand visitors. This is in accordance with the statement from the secretary of the Pulau Merah Pokmas who stated that the number of visitors in 2018 was 200 thousand visitors and in 2019 more than 300 thousand visitors. The tourists will spend money they bring in order to visit and enjoy the Pulau Merah tour to be satisfied. According on the results of interviews conducted in the study, it was found that the average amount of costs incurred by visitors per day was Rp.274,200.00. If the average is multiplied by the number of tourist visits to the Pulau Merah in March 2018, the fund that came in Sumberagung Village were Rp. 4,726,385,400.00. The number will continue to rotate resulting increasing in income of people who work in the tourism and non-tourism sectors as well as increase local income.

In Table 1 illustrate changes in the types of work of the Sumberagung Village community. The majority of community jobs after the development of the Pulau Merah tourist attraction are still working as farmers but have decreased in numbers significantly. People who work as agricultural laborers also experience a decline due to new jobs from the tourism sector. Mostly absorbed in the tourism sector where many people work as traders, inn services and restaurants or stalls. This number can be said to have increased considering that before the development of Pulau Merah the people who worked in the tourism sector were 630 people. From the various increases in labor absorbed, both from the 
tourism and non-tourism sectors, it can be said that the number of unemployed people in Sumberagung village has decreased. The impact of tourism in addition to income will also have an effect on the type of work done Public. According to Spillane [23], employment related to tourism can be divided into three categories, namely direct employment, indirect employment and work related to investment or infrastructure construction. Based on the data obtained from the Sumberagung Village Office, the community who work in the agricultural sector has decreased. This is because it is growing activities on tourism so that some farmers switch jobs. In the tourism sector itself has increased which consists of traders, tenants of lodging services and restaurants / stalls. This means that the tourism sector is capable provide employment for some of the Sumberagung Village community.

Table 1. Livelihood Comparison between Ecotourism Developments in Sumberagung Village

\begin{tabular}{|c|l|c|c|}
\hline No & Livelihood & $\begin{array}{c}\text { Before } \\
\text { ecotourism } \\
\text { development } \\
(\mathbf{2 0 0 9 )}\end{array}$ & $\begin{array}{c}\text { After } \\
\text { ecotourism } \\
\text { development } \\
\text { (2018) }\end{array}$ \\
\hline 1 & Farmer & 3070 & 4290 \\
\hline 2 & Farm labor & 4610 & 1973 \\
\hline 3 & Breeder & 205 & 50 \\
\hline 4 & Fisherman & 671 & 350 \\
\hline 5 & $\begin{array}{l}\text { Household } \\
\text { Craftsman }\end{array}$ & 6 & 3 \\
\hline 6 & Merchant & 339 & 684 \\
\hline 7 & Food stalls & 90 & 254 \\
\hline 8 & $\begin{array}{l}\text { Small } \\
\text { Entrepreneur }\end{array}$ & 13 & 76 \\
\hline 9 & $\begin{array}{l}\text { Large } \\
\text { Businessman }\end{array}$ & 0 & 2 \\
\hline 10 & $\begin{array}{l}\text { Private } \\
\text { Employees }\end{array}$ & 150 & 850 \\
\hline 11 & $\begin{array}{l}\text { Government } \\
\text { Employees }\end{array}$ & 45 & 68 \\
\hline 12 & $\begin{array}{l}\text { Medical } \\
\text { personnel }\end{array}$ & 0 & 12 \\
\hline 13 & Driver & 16 & 37 \\
\hline 14 & Tour Guide & 3 & 100 \\
\hline 15 & Inn Services & 1 & 112 \\
\hline & & & \\
\hline
\end{tabular}

The education level that was mostly achieved by the people of Sumberagung Village in 2018 which shown in Table 2 was the elementary school education level, which amounted to 3,475 people. Then followed by junior high school education level of 3,252 people. This proves that the level of community education is not classified as low at the 9-year compulsory education level. A total of 134 people has continued education to college. After development of Pulau Merah tourist attraction, there are changes in the level of community education which is quite significant. Sumberagung Village Community started to show awareness of the education so that the increase in education level will also improve the quality of human resources which will also improve the development process in the region.

Table 2. Education Level in Sumberagung Village

\begin{tabular}{|c|c|c|c|}
\hline \multicolumn{2}{|c|}{ Education Level } & Male & Female \\
\hline 1 & Elementary School & 1680 & 1795 \\
\hline 2 & Junior high School & 1675 & 1577 \\
\hline 3 & Senior high School & 1796 & 1850 \\
\hline 4 & Academic/Vocational & 363 & 388 \\
\hline 5 & University/College & 124 & 108 \\
\hline \multicolumn{2}{|c|}{ Total } & 5638 & 5718 \\
\hline
\end{tabular}

The potential for geographical characteristic conditions in Pulau Merah is very abundant which promises more advanced development in the future. of this potential, among others, natural resources in the form of coastal scenery as well as a beautiful Pulau Merah cluster. there are also lush trees of various shapes, fine white sand and wave conditions that are perfect for surfing activities. There are also land sports that will be developed by the management. These activities include outbound land, sunset views, ATV arena and sand games, such as beach volleyball and soccer. Extreme sports can also be done there by taking advantage of offshore areas such as surfing, windsurfing and water paragliding. The management and local governments often hold sports competitions and festivals as a purpose of promotion to attract more visitors, both local and international tourists. As an effort to maintain the attractiveness of ecotourism on Pulau Merah, the management also carries out developments that show added value so that it can be used as an education instrument for tourists, called diving tourism. diving tourism is developed in the form of enjoying and conserving coral reefs that involve tourists, where this activity also receives support from local and central governments. Ecotourism establishment requires a strategy that is determined from various interrelated aspects in order to create ideal conditions. Understanding the characteristics of environmental and geographical conditions which are the most important things in the development of ecotourism. the government also needs to create a conducive atmosphere with regulations capable of providing protection for economic activity.

The surrounding community as the affected parties and the existing culture also need to interact with ecotourism management so that inhibiting conflicts can be avoided. The availability of infrastructure needs to be improved as an effort to provide comfort for tourism stakeholders. The important role of the media and publications is also the carrying capacity that can have a significant impact on the development of ecotourism so that it can further attract outside investment which will provide financial support for operations and improve the quality of existing tourism. The development of ecotourism that occurs continuously also needs to be 
evaluated, especially from the demand side which can be used as analysis material for various parties, especially academics. Who's expected to provide positive recommendations so that sustainability could be well maintained. Further strategies in developing ecotourism can be carried out after conducting a deeper study of the results of field observations, interviews with tourism stakeholders and knowing the factors in the development of Pulau Merah beach which have an effect on increasing added value based on SWOT analysis. SWOT analysis is done by analyzing internal factors and external factors that occur.

The development of Pulau Merah beach as ecotourism which can have an impact on the socioeconomic resilience of the surrounding community requires strategic steps based on the observation of the existing impacts supported by a SWOT analysis in Table 3 to determine the internal and external factors that can provide an overview of the existing conditions of the charm of the Island coast Red.

The fact that the coast of Pulau Merah is the leading ecotourism in Banyuwangi with all aspects that appear both supportive and inhibiting has been widely studied. In line with the above thinking, a strategy is formulated that has a role in the aspects of advantages, consistency, consonance, and feasibility. In the advantage's strategy, it is necessary to increase the involvement of the community in all ages because this is an advantage in ensuring the sustainability of ecotourism that will run continuously. The next strategy is to ensure consistency in ecotourism activities based on the protection of laws and regulations established by the government. so that clarity about the code of conduct and control of the rules can create a conducive atmosphere in any ecotourism development activity.

Table 3. SWOT Matrix Analysis of Ecotourism in Pulau Merah

\begin{tabular}{|c|c|c|c|}
\hline & & Internal & \\
\hline & & Strength & Weakness \\
\hline & Factors Identification & $\begin{array}{l}\text { 1. Natural potential offered for } \\
\text { recreation } \\
\text { 2. tourist locations that are easily } \\
\text { accessible } \\
\text { 3. The security of the tourist } \\
\text { attraction area is very } \\
\text { guaranteed } \\
\text { 4. Various attractions of existing } \\
\text { ecotourism activities } \\
\text { 5. Affordable ticket price }\end{array}$ & $\begin{array}{l}\text { 1. Less organized tourist attractions } \\
\text { 2. Less vigorous promotion from } \\
\text { the manager } \\
\text { 3. Inadequate facilities and } \\
\text { infrastructure } \\
\text { 4. Communication networks are } \\
\text { still difficult to provide } \\
\text { 5. poor cooperation between the } \\
\text { District government and Forest } \\
\text { Agency (Perhutani) }\end{array}$ \\
\hline & Opportunity & $\mathrm{SO}$ & WO \\
\hline 苞 & $\begin{array}{l}\text { 1. Interest of tourists to visit ecotourism } \\
\text { still high } \\
\text { 2. There is attention from the central } \\
\text { government to Ecotourism } \\
\text { 3. Technological developments for ease } \\
\text { of promotion } \\
\text { 4. There are still many variations of } \\
\text { tourist attractions that can be } \\
\text { developed }\end{array}$ & $\begin{array}{l}\text { 1. Take advantage of the } \\
\text { development of digital era } \\
\text { technology to increase } \\
\text { information dissemination } \\
\text { 2. Improve the quality of service to } \\
\text { tourists } \\
\text { 3. Create branding that's easy to } \\
\text { catch } \\
\text { 4. Take advantage of low ticket } \\
\text { prices to attract market } \\
\text { segments } \\
\text { 5. Optimizing local community } \\
\text { involvement to support services }\end{array}$ & $\begin{array}{l}\text { 1. Improve the quality of the } \\
\text { communication network for } \\
\text { convenience } \\
\text { 2. Increase cooperation between } \\
\text { stakeholders in determining rules } \\
\text { and agreements that provide } \\
\text { mutual benefits } \\
\text { 3. Repairing and updating tourism } \\
\text { facilities and infrastructure }\end{array}$ \\
\hline & Threats & ST & WT \\
\hline & $\begin{array}{l}\text { 1. Tourism competition with other } \\
\text { tourist objects } \\
\text { 2. Foreign investors who are not } \\
\text { environmentally sound } \\
\text { 3. Abrasion and weather disturbance } \\
\text { 4. There was a natural disaster from the } \\
\text { sea } \\
\text { 5. Destructive action against the } \\
\text { environment around the coast }\end{array}$ & $\begin{array}{l}\text { 1. Making tourism products that } \\
\text { are different from other tourist } \\
\text { areas } \\
\text { 2. Provides a sense of security and } \\
\text { guarantees of safety for visitors } \\
\text { 3. Rehabilitating degraded } \\
\text { environmental conditions to } \\
\text { minimize disasters }\end{array}$ & $\begin{array}{l}\text { 1. Improve cooperation and } \\
\text { synergy between local } \\
\text { governments and Perhutani in } \\
\text { supervision } \\
\text { 2. Increase the competitiveness of } \\
\text { tourism that refers to sustainable } \\
\text { principles }\end{array}$ \\
\hline
\end{tabular}


A strategy that is also needed is consonance, which creates harmony between all aspects, not only the environment but also the human resources involved. Efforts to increase knowledge and awareness of ecotourism sustainability need to be instilled in all parties so that exploitation does not occur which over time will bring harm, especially the surrounding community and environment. Another strategy that needs to be implemented is to determine the feasibility of the ecotourism activities that have been developed. Guaranteeing decent conditions can be done with visitor satisfaction management. Emphasizing the importance of guaranteeing the satisfaction of visitors who are consumers of ecotourism services, it is something that needs to be prioritized because the survival of tourism activities is the presence of visitors. Visitor response will further provide an image on the tourist sites visited reflected in eco-friendly infrastructure. In the end, the implementation of these four strategies will create conditions to provide socio-economic resilience to indigenous peoples who live in the area around the coast of Pulau Merah.

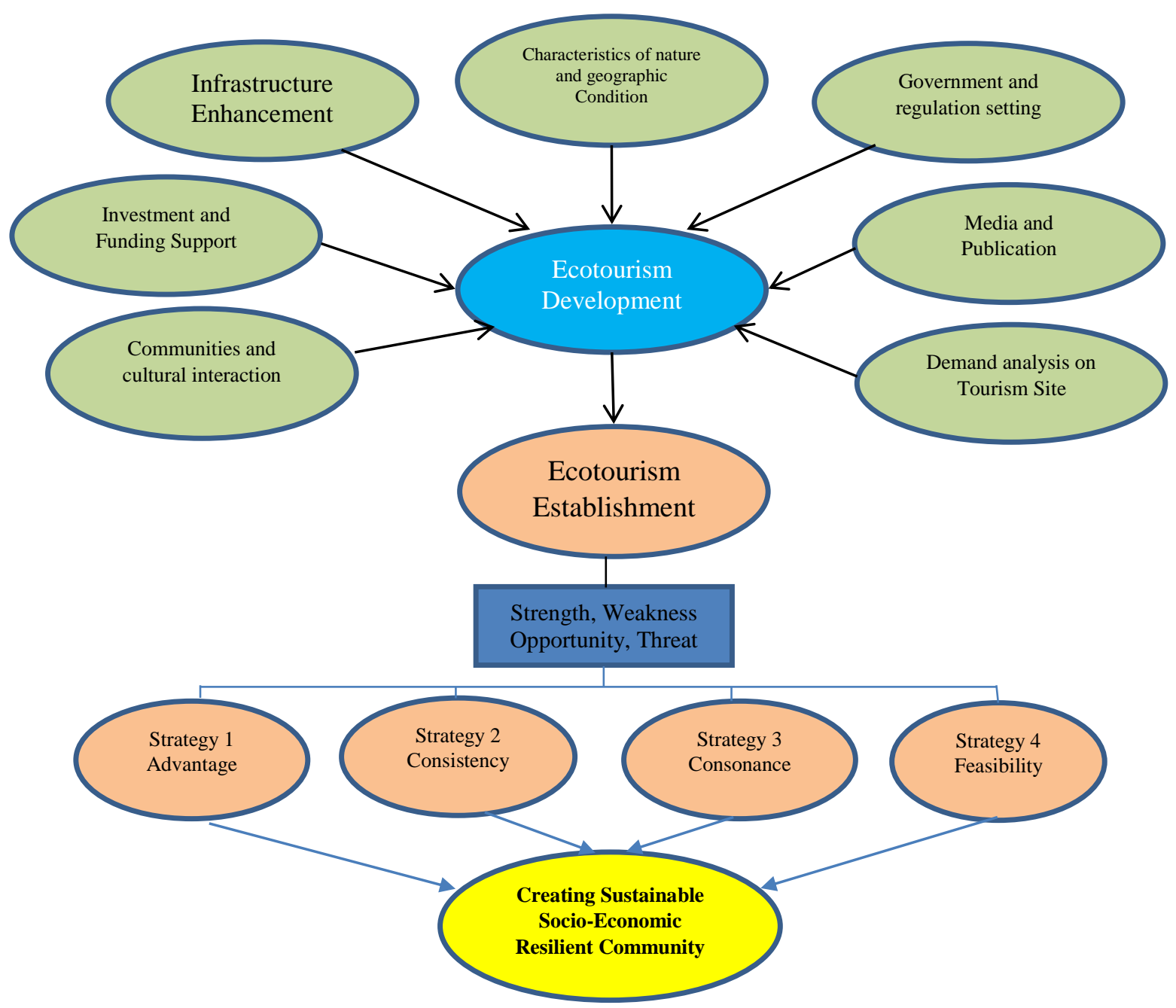

Figure 1. Strategy to create sustainable Socio-Economic Resilient Community

\section{CONCLUSION}

Based on the research results, it can be concluded that the development of the Red Island tourist attraction provides: (1) a direct impact on economic activities arising from the existence of tourist activities from the large number of visitors who come will result in a circulation of money in Sumberagung Village so that the income of the people who work in the tourism and non-tourism increases, (2) after the development of the Pulau Merah tourist attraction also resulted in an increase the number of people working in the tourism sector and the decline the number of people working in the agricultural sector, (3) the level of public education increases more and more many people continue to education up to college. Research recommendation about ecotourism strategies must be carried out to create significant impact on socio-economic activities. Based on the results of the analysis carried out, there are several strategies concern in aspects of advantage, consistency, consonance and feasibility. The implementation are by increasing the participation of 
local residents in all age and improving eco-friendly infrastructure as well as supporting regulations as legal protection for tourism activities and education for conserving nature.

\section{REFERENCES}

[1] Ministry of Tourism, Neraca Satelit Pariwisata Nasional. Jakarta: Kementerian Pariwisata, 2018.

[2] K. Lindberg, Policies for maximizing nature tourism's ecological and economic benefit. International conservation financing project working paper, World research institute, Washington DC, 1991.

[3] I Gde. Pitana, Sosiologi Pariwisata, Yogyakarta: Andi, 2005.

[4] Y. Luo, J. Deng, The New Environmental Paradigm and Nature-based Tourism Motivation. Journal of Travel Research, 46, p.392- 402, 2008.

[5] S. Ross and G. Wall, Ecotourism: toward congruence between theory and practice. Tourism Management 20, 1999.

[6] D.B. Weaver, The Encyclopedia of Ecotourism., CABI Publishing. New York, 2000.

[7] J. Stange, D. Brown, Solimar, Tourism destination Management: Achieving Sustainable and Competitive Results, Washington: International Institute for Tourism Studies, 2002.

[8] R. Rumelt, The Evolution Of Business Strategy. Dalam Heri (Ed), The Strategy Process. Englewood, 1997.

[9] R.K. Blamey, Principles of Ecotourism, Encyclopaedia of Ecotourism, Wallingford, United Kingdom: CABI ed , 2001.

[10] G.Wall, Is Ecotourism sustainable? Environmental Management. 21(4): pp-483-491, 1997.

[11] B.H. Farrell, D. Runyan, Ecology and Tourism, Annals of Tourism Research.;18: pp-26-40 Cliffs: Prentice Hall1991.

[12] D. Western, Defining Ecotourism, Ecotourism Society, 1993. https://www.cabdirect.org/cabdirect/abstract/19941 800464

[13] M.Valtonen, Ecotourism and Sustainability: Social Impacts on Rural Communities. Bechelores thesis, Laurea University of Applied Sciences, 2013.

[14] S. Wearing, J. Neil, Ecotourism: Impacts, potentials and possibilities?, New south wales. Elsevier, books.google.com, 2009.
[15] R. Scheyvens, Ecotourism and the empowerment of local communities, Tourism management Elsevier, 1999. https://doi.org/10.1016/S02615177(98)00069-7

[16] Taylor, J. Edward; Yunez-naude, Antonio; Dyer, Geroge A.; Stewart, Micki; and Ardila, Sergio. "The Economics of Eco-tourism": A Galapagos Island Economy-wide Perspective", Environment and Development Economics, 14.2.139-162, 2002.

[17] C. Fandeli, Perencanaan Kepariwisatan Alam. PT (persero) Perhutani dan Fakultas Kehutanan Universitas Gajahmada, Yogyakarta, 2002.

[18] D.J. Timothy, "Empowerment and Stakeholder Participation in Tourism Destination Communities", in A. Church and T. Coles (eds) Tourism, Power and Space (pp. 199-216). London and New York: Routledge. 2007.

[19] N, Chesworth, Ecotourism seminar paper delivered in the Institute of Environmental Studies and Management, UPLB College, Laguna, 1995.

[20] H.Mintzberg, B. Ahlstrand, J.Lampel, Strategy Safari: A Guided Tour Through The Wilds Of Strategic Management. New York: The Free Press, 1998.

[21] A. Drumm, Ecotourism Development - A Manual for Conservation Planners and Managers Volume 1: An Introduction to Ecotourism Planning, Second Edition. The Nature Conservancy, Arlington, Virginia, USA, 2005.

[22] BAPPEDA Kabupaten Banyuwangi, Rencana Kerja Pembangunan Daerah Kabupaten Banyuwangi 2016-2021, Banyuwangi: BAPPEDA Kabupaten Banyuwangi, 2019.

[23] J.J. Spillane, Ekonomi Pariwisata: Sejarah dan Prospeknya, Yogyakarta: Kanisius, 1997. 